\title{
Condom use and migration in a sample of Mexican migrants: potential for HIV/STI transmission
}

\author{
Raquel Fosados, MPH, (1) Ramiro Caballero-Hoyos, Dr. CS,(2) \\ Teresa Torres-López, DA, ${ }^{(3)}$ Thomas W.Valente, PhD. ${ }^{(1)}$
}

\begin{abstract}
Fosados R, Caballero-Hoyos R, Torres-López T, Valente TW. Condom use and migration in a sample of Mexican migrants: potential for HIV/STI transmission. Salud Publica Mex 2006;48:57-6I.
\end{abstract}

\begin{abstract}
Objective.To analyze the association between condom use and migration to the United States (US) in two Mexican municipalities. Material and Methods. A cross-sectional, non-probabilistic study of egocentric social networks was conducted in Cuauhtémoc, Colima and Tonalá, Jalisco during the months of December 2003 and January 2004, in 354 migrant subjects. Migration, sexual network, history and risk for sexually transmitted infections (STIs) characteristics were surveyed. Statistical analyses was conducted using logistic regression. Results. Increased migration travel to the US was significantly associated with consistent condom use for Cuauhtémoc (OR: 3.87; $p<0.05$ ) and Tonalá (OR: 4.I2; $p<$ $0.05)$ municipalities. Other significant predictors included: age, type of sex partner, and perceived monogamy. Conclusions. Our data support the hypothesis that migration to the US is associated with condom use.
\end{abstract}

Key words: social networks; migration; condoms; HIV/AIDS; Mexico
Fosados R, Caballero-Hoyos R, Torres-López T,Valente TW. Uso de condón y migración en una muestra de migrantes mexicanos: potencial para la transmisión de VIH/ITS.

Salud Publica Mex 2006;48:57-6I.

\section{Resumen}

Objetivo.Analizar la asociación entre el uso del condón y la migración a Estados Unidos en dos municipios mexicanos. Material y métodos. Estudio transversal no probabilístico de redes sociales egocéntricas. Muestra de 354 migrantes. Cuestionario sobre prácticas y redes sexuales, historia de ITS y migración. Análisis mediante regresiones logísticas. Resultados. La mayor experiencia migratoria se asoció significativamente al uso consistente del condón en Tonalá (RM: $4.12 ; p<.05)$ y Cuauhtémoc (RM: $3.87 ; p<.05)$. Otros predictores fueron: edad, tipo de pareja y percepción de la fidelidad. Conclusión. Los datos apoyan la hipótesis de la asociación entre la migración y el uso del condón.

Palabras clave: redes sociales; migración; condón;VIH/SIDA; México

Este trabajo fue realizado con el apoyo financiero del Fondo para el Fomento de la Investigación Médica del Instituto Mexicano del Seguro Social, proyecto número FP-2003/l 47.

(I) Department of Preventive Medicine, Keck School of Medicine, University of Southern California,

(2) Instituto Mexicano del Seguro Social, Unidad de Investigación Epidemiológica y en Servicios de Salud del Adolescente, Unidad de Medicina Familiar, Tonalá, Jalisco, México.

(3) Universidad de Guadalajara, Departamento de Salud Pública, Guadalajara, Jalisco, México. 
E arly international studies on migrant health showed that the dissemination of infectious diseases, including sexually transmitted infections (STIs) and HIV, could be intensified and accelerated by migrating populations. ${ }^{1}$ In fact, in regions where HIV is endemic, population mobility is an independent risk factor for HIV. ${ }^{2}$ Although this finding does not suggest that migrants are disease carriers, it does, however, suggest that migration can establish vulnerability to HIV. ${ }^{2-10}$ This is especially true when migrants lack proper health care and / or are unable to meet their basic needs.

Social networks have been applied to and have increased our understanding of how the structure of groups of people can increase or protect from HIV transmission by taking into consideration within-group influences. ${ }^{11}$ The basic hypothesis in social networks posits that behaviors occur within social frameworks made up of individuals, and the relationships between individuals influence the risk for disease transmission and propagation. ${ }^{11}$

The purpose of the current study was to analyze the association between condom use, within the context of sex partner networks, and variables that measure migratory experience to the United States (US), among a sample of male migrants from two Mexican municipalities with different population densities.

\section{Material and Methods}

The data in this article come from an anonymous health behavior study conducted in Cuauhtémoc, Colima and Tonalá, Jalisco during the months of December 2003 and January 2004. These municipalities were selected on the basis of their differing rates of extensive international migration to the US and population densities typical of the migratory process ${ }^{12}(<15000$ inhabitants in Cuauhtémoc; >100000 inhabitants in Tonalá); and registered HIV / AIDS cases.

Participants completed an interviewer-administered questionnaire after being recruited through street outreach. Data on egocentric sexual networks, including various alter attributes were collected. ${ }^{13-18}$ Migration and socioeconomic data were also collected. Eligibility criteria consisted of: a) males between ages $18-55 ; b$ ) who reported legal or illegal residence in the US at least once during the past three years; and c) who reported at least one sex partner in the past year. A total of 354 migrants agreed to participate; the refusal rate was estimated at $20 \%$. Procedures for the ethical treatment of subjects were followed, including written informed consent and voluntary participation. This study was approved by the research and ethics committee of the Unidad Médica Familiar \# 93 of IMSS Jalisco.
Data were converted to dyadic format ${ }^{15,19}$ and analyzed together and separately by municipality (chisquare; $t$-test). The associations between condom use (categorized as always and any condom use) and US migration history, adjusted for other covariates, were analyzed using logistic regression. All data analyses were conducted with the SAS statistical package.

\section{Results}

Demographic characteristics are shown in Table I. The mean age of study subjects was 32.8 years; $55.6 \%$ were married/living with partner; $66 \%$ had middle school education or less; and 7.9\% spoke an indigenous language.

Regarding migration, $75 \%$ of subjects reported having made two or more trips to the US; $50.8 \%$ of them reported having stayed one year or longer during their last US visit; 59\% had authorization to cross the US border. Regarding sexual health behaviors, $45 \%$ of migrants reported always using a condom with their sex partner and $17.3 \%$ reported at least one STI symptom in the past year.

Table II shows the results of logistic regression analyses. Reporting two or more trips to the US was significantly associated with consistent condom use (OR: 3.09; $p<0.05)$. Other significant variables included: reporting two or more sex partners in the past year (OR: 2.76); sex partner who was a mistress (OR: 8.00) or a friend (OR: 3.34); and a non-monogamous partner (OR: 4.93). However, alcohol consumption prior to sexual intercourse was not significantly associated with consistent condom use. When separated by municipality, two or more trips to the US continued to be significantly associated with consistent condom use. Of interest is that age was no longer a significant predictor of consistent condom use in Cuauhtémoc (OR: 0.65; $p>0.05$ ). Results of the logistic regression on any condom use were somewhat similar to those of consistent condom use.

\section{Discussion}

We evaluated factors associated with condom use among a sample of migrant Mexican males from Cuauhtémoc, Colima and Tonalá, Jalisco. Our findings indicated that increased experience in the migratory process, measured by the number of trips made to the US, was associated with higher condom use. Consistent condom users were also single, more educated older males ( $\geq 35$ years of age) who engaged in protective behaviors, especially when they had two or more sex partners or non-steady partners, and when their sex partner was not monogamous. Our results are confirmed by others. ${ }^{7,10,21}$

salud pública de méxico / vol.48, no.1, enero-febrero de 2006 
Table I

Characteristics of migrants in Cuauhtémoc, Colima and Tonalá, Jalisco, México, 2003-2004

Variables

Age* (mean)

Marital Status ${ }^{\ddagger}$

Married, w/partner

Divorced, separated, widowed

Single or widowed
Cuauhtémoc, Colima

$n=205$

$33.1(9.1)$
Tonalá, Jalisco

$n=149$

$32.5(13.0)$

$78(52.3 \%)$

$119(58.0 \%)$

$7(3.4 \%)$

$79(38.5 \%)$

$8(5.4 \%)$

$63(42.3 \%)$ p-value (chi-square test)

0.64 0.47

Highest Level of Education ${ }^{\ddagger}$ None or Elementary School

6I $(29.8 \%)$

$73(35.6 \%)$

$55(26.8 \%)$

$16(7.8 \%)$

Vocational School/University/Other

Speak indigenous language $\mathrm{e}^{\ddagger}$

Yes

$25(12.2 \%)$

$180(87.8 \%)$

$3(2.0 \%)$

$139(93.3 \%)$

$50(33.5 \%)$

$5 \mathrm{I}(34.0 \%)$

$35(23.5 \%)$

$12(8.1 \%)$

0.51

Household size* (mean)

Number of people in the home

$4.2(1.6) \quad 4.9(2.1)$

Number of employed household member

$1.9(1.0)$

$2.4(1.6)$

Employment status past 3 months ${ }^{\ddagger}$

Unemployed

$5(2.4 \%)$

$193(94.1 \%)$

$7(3.4 \%)$

Employed

Looked for employment, Other

$7(3.4 \%)$

0.15

Number of migration trips to US

$\begin{array}{rr}42(20.6 \%) & 36(25.0 \%) \\ 162(79.4 \%) & 108(75.0 \%)\end{array}$

Two or more

$162(79.4 \%)$

$08(75.0 \%)$

Length of past US stay ${ }^{\ddagger}$

$82(40.6 \%) \quad 84(58.3 \%)$

Less than I year

$120(59.4 \%)$

$60(41.7 \%)$

Authorization to cross US border§

0.93

Yes

$120(58.8 \%)$

$87(58.4 \%)$

$84(41.2 \%)$

$62(41.6 \%)$

Frequency of condom use with past year sex partners $\$$

\begin{tabular}{lrr} 
Always & $80(35.7 \%)$ & $78(45.3 \%)$ \\
\hline Sometimes & $34(15.2 \%)$ & $24(14.0 \%)$ \\
\hline Rarely & $5(2.2 \%)$ & $9(5.2 \%)$ \\
\hline Never & $105(46.9 \%)$ & $61(35.5 \%)$
\end{tabular}

History of STI symptoms ${ }^{\ddagger}$

\begin{tabular}{lrr} 
None & $148(72.2 \%)$ & $91(61.1 \%)$ \\
\hline At least one symptom & $27(13.2 \%)$ & $23(15.4 \%)$ \\
\hline Missing & $30(14.6 \%)$ & $35(23.5 \%)$
\end{tabular}

* Mean age with standard deviation in parenthesis

\# Frequency with percentage in parentheses

$\S$ Total exceeds sample size because individual condom use with up to 8 sex partners was asked 
Table II

Factors associated With condom use among migrants in Cuauhtémoc, Colima and Tonalá, Jalisco, México, 2003-2004, Adjusted Odds Ratios

\begin{tabular}{|c|c|c|c|c|c|}
\hline \multirow[b]{2}{*}{ Variables } & \multicolumn{3}{|c|}{ Always used condoms } & \multicolumn{2}{|c|}{ Any condom use } \\
\hline & All & Cuauhtémoc* & Tonaláf & All & Cuauhtémoc* \\
\hline \multicolumn{6}{|l|}{ Age } \\
\hline$\leq 34$ & 1.00 & - & - & 1.00 & - \\
\hline$\geq 35$ & $4.59 \$$ & 0.65 & $\left.13.9\right|^{\S}$ & 1.11 & 0.09 \\
\hline
\end{tabular}

Education Level

\begin{tabular}{|c|c|c|c|c|c|c|}
\hline None/Preschool/Elementary School & 1.00 & - & - & 1.00 & - & - \\
\hline Middle School & $2.22^{\S}$ & 0.52 & $5.17^{\S}$ & $1.94^{\S}$ & 1.38 & 1.84 \\
\hline High School & $3.37^{8}$ & $3.68^{8}$ & $4.58 \S$ & $2.86^{\S}$ & $4.14^{\S}$ & 2.98 \\
\hline Vocational/University & $4.40^{\S}$ & 1.14 & $8.79 \$$ & 0.98 & 0.61 & 1.05 \\
\hline
\end{tabular}

Marital Status

\begin{tabular}{|c|c|c|c|c|c|c|}
\hline Single & 1.00 & - & - & 1.00 & - & - \\
\hline Married & $0.36^{\#}$ & $0.08^{\#}$ & $0.27^{\S}$ & 0.65 & $0.36^{8}$ & 0.68 \\
\hline
\end{tabular}

Relationship variables

Number of sex partners in past year

\begin{tabular}{|c|c|c|c|c|c|c|}
\hline One & 1.00 & - & - & 1.00 & - & - \\
\hline Two or more & $2.76^{\#}$ & $4.92^{8}$ & 1.88 & $1.91^{\S}$ & 1.62 & 2.16 \\
\hline \multicolumn{7}{|l|}{ Type of intercourse } \\
\hline Vaginal & 1.00 & - & - & 1.00 & - & - \\
\hline Oral & 0.91 & 0.26 & 1.59 & 1.32 & 0.81 & 3.9 \\
\hline Anal & 0.198 & 0.43 & $0.05^{\#}$ & 1.52 & $4.21^{\S}$ & 0.28 \\
\hline
\end{tabular}

Type of relationship with sex partner Spouse/Steady partner

Mistress

Friend

$\begin{array}{lccccc}1.00 & - & - & 1.00 & - & - \\ 8.00^{\S} & 4.00 & 14.178 & 2.09 & 0.54 & >99.99 \\ 3.34^{\#} & 5.53^{\S} & 2.78^{\S} & 2.50^{\S} & 4.77^{\S} & 1.96\end{array}$

Place first sexual encounter occurred

Mexico 1.00

1.00

.60

$-$

-
-

Sex partner had sex w/someone else

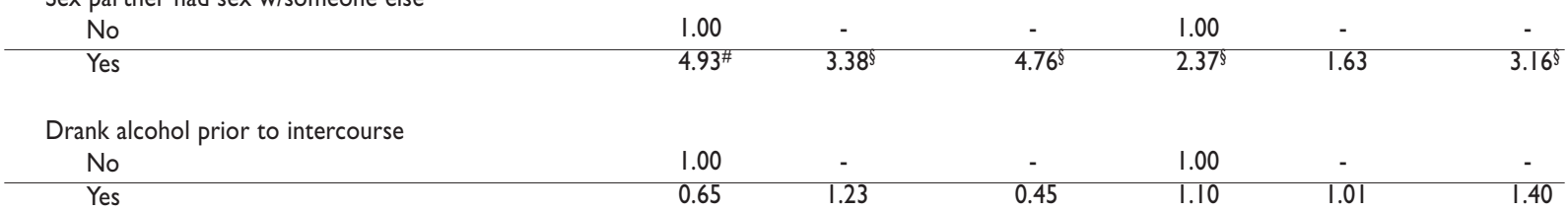

History of STIs

None

$\begin{array}{llllll}1.00 & - & - & 1.00 & -\end{array}$

Migration variables

Number of trips to the US One

Two or more

1.00

3.09

$\quad 1.00$

ength of past US stay

Less than I year

A year or more

1.00

0.64

0.43

$\begin{array}{cc}- & 1.00 \\ 0.88 & 0.65\end{array}$

0.42

1.66

* Dyadic sample size for Cuauhtémoc $=1035$

‡ Dyadic sample size for Tonalá= 799

$\S p<.05$

$\# p<.001$ 
These results indicate there is something more to the migratory experience, in particular circular migration, that may affect condom use. Perhaps with each subsequent trip to the US, the perception of increased risk of HIV / STIs infection occurs. Or perhaps, the sporadic exposure to HIV/STIs prevention messages while in the US leads to increased consistent condom use. Future studies inquiring into migrants' exposure to HIV/STIs prevention messages may provide enlightenment.

However, an explanation as to why the length of US stay is not associated with condom use may have to do with acculturation. In the literature, length of US stay has been used as a proxy to measure acculturation..$^{20-24}$ Perhaps increased migratory trips to the US are indicative of lower acculturation in our sample because of their eventual return to Mexico. Future studies conducted with Mexican migrating populations should perhaps consider investigating acculturation further.

Results of our study shed light on the HIV/STIs protective behaviors of Mexican male migrants. However, it is important to keep in mind that this study has a major limitation with respect to the accuracy of selfreported sexual behaviors, in particular information provided about alter attributes, due to the effects of social desirability. Another limitation is the non-random, non-probabilistic sampling technique employed to interview participants. Therefore, there is limited generalizability of study results.

\section{Acknowledgements}

We thank the community health workers and nurses in Cuauhtémoc, Colima and the students at the Universidad de Guadalajara for their contribution to this study.

Partial support for this research was provided by the National Institute on Drug Abuse, Grant DA16094.

\section{References}

I. Mabey D, Mayaud P. Sexually transmitted infections in mobile populations. Genitourin Med 1997;73:18-22.

2. Decosas J, Kane F, Anarfi JK, Sodji KDR, Wagner HU. Migration and AIDS. Lancet 1995;346:826-828.

3. Cárdenas-Elizalde MR. Migración y SIDA en México. Salud Publica Mex 1988;30:613-618.

4. Bronfman M, Campos-Ortega S, Medina H. La migración internacional y el SIDA: el caso de México y Estados Unidos. En: Sepúlveda-Amor J, Bronfman M, Ruiz-Palacios G, Stanislawski E, Valdespino JL. SIDA, ciencia y sociedad en México. México, D.F: INSP-FCE, 1989:435-456. 5. Bronfman M, Minello N. Hábitos sexuales de los migrantes temporales mexicanos a los Estados Unidos de América. Prácticas de riesgo para la infección porVIH. En: Bronfman M, ed. SIDA en México.
Migración, adolescencia y género. México D.F.: Información Profesional Especializada, 1995:3-89.

6. Magaña JR. Sex, drugs and HIV: an ethnographic approach. Soc Sci Med 1991;33:5-9.

7. Organista KC, Balls-Organista P, García de Alba JE, Castillo-Morán MA, Ureta-Carrillo LE. Survey of condom related beliefs, behaviors and perceived social norms in Mexican migrant laborers. J Community Health 1997;22:185-198.

8. Salgado de Snyder N. Migración, sexualidad y SIDA en mujeres de origen rural: sus implicaciones psicosociales. En: Sasz I, Lerner S. comp. Sexualidades en México. Algunas aproximaciones desde la perspectiva de las ciencias sociales. México D.F.: El Colegio de México, 1998:155-171. 9. Hirsch JS, Higgins J, Bentley ME, Nathanson CA. The Social Constructions of Sexuality: Marital Infidelity and Sexually Transmitted Disease-HIV Risk in a Mexican Migrant Community. Am J Public Health 2002; 92:1227-1237.

I0. Magis-Rodriguez C, Gayet C, Negroni M, Leyva R, Bravo-García E, Uribe P, Bronfman M. Migration and AIDS in Mexico.An Overview Based on Recent Evidence.) Acquir Immune Defic Syndr 2004;37 (Suppl 4):215-226.

II. Rothenberg R. How a Net Works. Implications for Network Structure and Control of Sexually Transmitted Infections and HIV. Sex Transm Dis 200I;28:63-68.

12. Marcelli EA, Cornelius WA. The changing profile of Mexican Migrants to the United States: New Evidence from California and Mexico. Latin American Research Review 2001;36:105-131.

13. ONUSIDA. Resumen mundial de la epidemia delVIH/SIDA.

Diciembre de 2002. Ginebra, Suiza: ONUSIDA y OMS; 2002. pp. 3-8.

Disponible en: http://www.unaids.org/worldaidsday/2002/press/update/ epiupdate sp.pdf.

14. Neaigus A, Friedman SR, Goldstein M, Ildefonso G, Curtis R, Jose B. Using dyadic data for a network analysis of HIV infection and risk behaviors among injecting drug users. In: Needle R, Genser SG, Trotter RT, eds. Social Networks, Drug Abuse, and HIV Transmission. Rockville, MD: National Institue on Drug Abuse, 1995:20-37. NIDA Reserach Monograph I5I.

I5.Valente TW,Vlahov D. Selective risk taking among needle exchange participants: Implications for supplemental interventions. Amer J Public Health 200I;91:406-4II

16. Marsden, P.V. (1990). Network data and measurement. Annual Review of Sociology, 16,435-463.

17. Marsden, P.V. (1987). Core discussion networks of Americans. American Sociological Review, 52, I22-131.

18. Campbell, K. E. and Lee, B. A. (199I). Name generators in surveys of personal networks. Social Networks, 13, 203-22I.

19. Neaigus A, Friedman SR, Goldstein M, Ildefonso G, Curtis R, Jose B. Using dyadic data for a network analysis of HIV infection and risk behaviors among injecting drug users. In: Needle R, Genser SG, Trotter RT, eds. Social Networks, Drug Abuse, and HIV Transmission. Rockville, MD: National Institue on Drug Abuse, 1995:20-37. NIDA Reserach Monograph I5I.

20. Organista KC, Organista PB, Garcia de Alba JE, Castillo-Moran MA, Carrillo H.AIDS and condom-related knowledge, beliefs, and behaviors in Mexican migrant laborers. Hisp J Behav Sci 1996;18:392-405.

21. Gurman T, Borzekowski DL. Condom use among Latino college students. J Amer College Health 2004;52:169-178.

22. Himmelgreen DA, Pérez-Escamilla R, Martinez D, Bretnall A, Eells B, Peng Y, Bermúdez $A$. The longer you stay, the bigger you get: length of time and language use in the U.S. are associated with obesity in Puerto Rican women.Am J Phys Anthropol 2004; 125:90-96.

23. Alarcon GS. Rodriguez JL. Benavides G Jr. Brooks K. Kurusz H. Reveille JD. Systemic lupus erythematosus in three ethnic groups: Acculturation, health-related attitudes and behaviors, and disease activity in Hispanic patients from the LUMINA cohort. Arthritis Care Res 1999;12:267-276.

24. Marin BV, Gomez CA, \& Tschann JM. Condom use among Hispanic men with secondary female sexual partners. Public Health Rep 1993; 108:742-750. 